\title{
IMPLEMENTASI PERDA KOTA DUMAI TENTANG RETRIBUSI PELAYANAN PASAR
}

\author{
Anto Ariyanto' ${ }^{1)}$ dan Suyanto, $\mathrm{SH}, \mathrm{MH}^{2)}$ \\ ${ }^{1)}$ Staf pengajar Faperta dan ${ }^{2)}$ Fakultas Hukum Univ. Lancang Kuning
}

\begin{abstract}
ABSTRAK. Dengan adanya Undang-Undang Nomor 32 tahun 2004 tentang Pemerintah Daerah, maka pasar tidak hanya sebagai unit pelayanan kepada masyarakat, tetapi pasar sudah merupakan unit usaha bagi pemerintah daerah sehingga diharapkan dapat menghasilkan laba retribusi. Dari berbagai macam retribusi yang dipungut oleh Pemerintah Kota Dumai, yang potensial adalah retribusi pasar, karena diharapkan mampu memberikan kontribusi yang cukup besar terhadap penerimaan daerah dibandingkan dengan retribusi yang lain. Hal ini dikarenakan Kota Dumai setidaknya mengelola 15 pasar tradisional dan dari kesemua pasar tersebut ditarik retribusi pasar. Dengan meningkatnya kehidupan perekonomian Kota Dumai.

Tujuan yang ingin dicapai dari penelitian ini adalah: 1) menjelaskan kontribusi penerimaan retribusi pasar terhadap perolehan pendapatan asli daerah, khususnya pada Pemerintah Daerah Kota Dumai. 2) mengetahui bagaimana tingkat pertumbuhan retribusi pasar di Kota Dumai 3) mengetahui apakah pemungutan retribusi pasar di Kota Dumai selama lima tahun anggaran sudah efektif.

Pendekatan yang digunakan dalam penulisan penelitian ini adalah mencoba untuk memadukan pendekatan kualitatif dan kuantitatif dari berbagai sumber data yang diperoleh, yang relevan untuk menjawab pertanyaan penelitian. Analisis data yang digunakan dalam penelitian ini adalah : 1) kontribusi retibusi 2) tingkat pencapaian target 3) elastisitas dan 4) analisis trend.

Hasil penelitian menunjukkan bahwa kontribusi penerimaan Retribusi Pelayanan Pasar Kota Dumai terhadap Pendapatan Asli Daerah (PAD) Kota Dumai tahun anggaran 2006 - 2010 masih kecil, karena rata-rata masih dibawah 1 persen, yaitu rata-rata hanya sekitar 0.23 persen. Tingkat pertumbuhan Retribusi Pelayanan Pasar Kota Dumai secara umum terjadi penurunan tingkat pertumbuhan penerimaan retribusi pelayanan pasar sejak tahun anggaran 2006 hingga 2010. Sedangkan tingkat efektifitas Retribusi Pelayanan Pasar Kota Dumai selama tujuh tahun dari tahun anggaran 2005 sampai dengan tahun anggaran 2011 bisa dikatakan tercapai. Dengan melihat rata-rata efektifitas rata-rata sebesar 103.45 persen setiap tahunnya.
\end{abstract}

Kata Kunci : Perda, Retribusi, Pasar, PAD, Efektifitas. 


\section{PENDAHULUAN}

\section{Latar Belakang}

Salah satu usaha yang dilakukan oleh Pemerintah Daerah dalam mengelola Retribusi Pasar ini adalah memberikan pelayanan kepada masyarakat sesuai dengan apa yang telah mereka bayarkan kepada pemerintah. Keberadaan pelayanan ini dirasakan cukup penting sebagai aspek yang harus dilakukan dalam tatanan pengelolaan pemerintahan yang baik di daerah itu sendiri.

Pelayanan publik sebagai indikator utama bagi Pemerintah Daerah dalam menyelenggarakan pemerintahan harus dilaksanakan sesuai dengan peraturan yang berlaku dan dikelola dengan baik, karena pengelolaan retribusi pasar tidak dapat dilepaskan dari pelayanan yang diberikan. Pengelolaan retribusi pasar diharapkan dapat dirasakan oleh masyarakat pengguna jasa pasar.

Dengan adanya Undang-Undang Nomor 32 tahun 2004 tentang Pemerintah Daerah, maka pasar tidak hanya sebagai unit pelayanan kepada masyarakat, tetapi pasar sudah merupakan unit usaha bagi pemerintah daerah sehingga diharapkan dapat menghasilkan laba retribusi. Apabila hal itu dapat terpenuhi, maka sumber pendapatan dapat digunakan oleh Pemerintah Kota Dumai untuk meningkatkan pelayanan kepada masyarakat dan pada akhirnya dapat untuk meningkatkan kemakmuran masyarakat Dumai.

Dari berbagai macam retribusi yang dipungut oleh Pemerintah Kota Dumai, yang potensial adalah retribusi pasar, karena mampu memberikan kontribusi yang cukup besar terhadap penerimaan daerah dibandingkan dengan retribusi yang lain. Hal ini dikarenakan Kota Dumai setidaknya mengelola 15 pasar tradisional dan dari kesemua pasar tersebut ditarik retribusi pasar. Dengan meningkatnya kehidupan perekonomian Kota Dumai, maka akan memberikan pengaruh pada tingkat konsumsi masyarakat Dumai. Perkembangan kehidupan perekonomian yang akan mempengaruhi tingkat konsumsi masyarakat harus didukung adanya fasilitas bagi masyarakat untuk mengadakan kegiatan ekonomi.

Pasar adalah salah satu fasilitas bagi masyarakat untuk mengadakan kegiatan ekonomi. Dengan adanya pasar, maka akan tercipta siklus perputaran uang bagi peningkatan kehidupan perekonomian masyarakat Kota Dumai. Peningkatan perekonomian tersebut secara tidak langsung berdampak bagi Pemerintah Kota Dumai untuk senantiasa mengembangkan pasar-pasar yang dikelola oleh pemerintah 
yang juga digunakan sebagai potensi penerimaan daerah. Oleh karena itu, semakin baik pengelolaan terhadap pasar-pasar yang dikelola, maka akan berdampak pada pengembangan penerimaan retribusi pasar.

Penelitian ini akan mengkaji dan menggali mengenai aspek-aspek pendapatan pemerintah daerah di Kota Dumai, khususnya yang berkaitan dengan retribusi pelayanan pasar, setelah ditetapkannya Peraturan Daerah Kota Dumai Nomor 8 Tahun 2002 tentang Retribusi Pelayanan Pasar, yang selanjutnya disempurnakan oleh Peraturan Daerah Kota Dumai No. 21 tahun 2011 tentang Retribusi Pelayanan Pasar.

\section{Tujuan Penelitian}

Tujuan yang ingin dicapai dari penelitian ini adalah: 1) menjelaskan kontribusi penerimaan retribusi pasar terhadap perolehan pendapatan asli daerah, khususnya pada Pemerintah Daerah Kota Dumai, 2) mengetahui bagaimana tingkat pertumbuhan retribusi pasar di Kota Dumai dan 3) mengetahui apakah pemungutan retribusi pasar di Kota Dumai selama lima tahun anggaran sudah efektif.

\section{METODE PENELITIAN}

Penelitian ini dilaksanakan di Pemerintahan Daerah Kota Dumai Propinsi Riau, khususnya pada Kantor Pelayanan Pasar Kota Dumai. Pendekatan yang digunakan dalam penulisan penelitian ini adalah mencoba untuk memadukan pendekatan kualitatif dan kuantitatif dari berbagai sumber data yang diperoleh, yang relevan untuk menjawab pertanyaan penelitian. Ada dua macam teknik pengumpulan data yang dipergunakan dalam penulisan penelitian ini, yaitu: Studi Pustaka dan time series analisis

Analisis yang digunakan dalam penelitian adalah

1) Kontribusi Retribusi Pelayanan Pasar Terhadap PAD dengan rumus :

$$
\text { Kontribusi }=\frac{\text { Penerimaan Retribiusi tahun } k e-n}{\text { Penerimaan PAD tahun ke-n }} \times 100 \%
$$

2) Tingkat Pencapaian Target ( TPT ) yaitu hubungan antara hasil penerimaan retribusi dari retribusi terhadap potensi retribusi untuk mengetahui apakah potensi yang ditetapkan pada awal tahun anggaran dapat dicapai pada akhir periode tahun anggaran. Selain itu juga berguna untuk mengetahui apakah kinerja dalam pelaksanaan pemungutan retribusi telah efektif, dengan rumus : 


$$
T P T=\frac{\text { Realisasi Penerimaan Retribiusi tahun ke }-n}{\text { Target Penerimaan Retribusi tahun ke-n }} \times 100 \%
$$

3) Elastisitas, yang bertujuan untuk mengetahui kepekaan perubahan retribusi yang menyebabkan perubahan PAD. Untuk menghitung elastisitas digunakan rumus sebagai berikut:

$$
\text { Elastisitas }=\left|\frac{\Delta X}{\Delta Y}\right| x \frac{Y}{X}
$$

Dimana, $\Delta \mathrm{X}$ : Perubahan penerimaan $\mathrm{PAD}, \Delta \mathrm{Y}$ : Perubahan penerimaan retribusi, $\mathrm{X}$ : Penerimaan PAD dan Y : Penerimaan retribusi. Dengan kriteria pengujian $\varepsilon<1$ bersifat inelastis, $\varepsilon=1$ bersifat unitary elastis, dan $\varepsilon>1$ bersifat elastis.

4) Analisa Trend, adalah rata-rata perubahan ( biasanya setiap tahun ) dalam jangka panjang. Persamaan trend dapat dituliskan dengan menggunakan rumus sebagai berikut $\mathrm{Y}^{\prime}=\mathrm{a}+\mathrm{bX}$ dimana : $\mathrm{Y}^{\prime}$ : nilai trend, $\mathrm{a}:$ Bilangan konstanta, $\mathrm{b}:$ Slope atau lereng garis Trend dan X : Periode waktu (mewakili waktu). Jika nilai Trend menunjukkan kenaikan atau positif berarti menunjukkan bahwa realisasi retribusi selalu meningkat dan bila sebaliknya maka realisasi retribusinya turun.

\section{HASIL DAN PEMBAHASAN}

\section{Potensi Retribusi Pelayanan Pasar Kota Dumai}

Retribusi pelayanan pasar yang dikelola oleh Kantor Pelayanan Pasar Kota Dumai merupakan salah satu pos penerimaan yang cukup potensial pada sektor retribusi daerah. Kondisi ini tentunya retribusi pasar berpotensi memberikan sumbangan yang cukup penting bagi sektor penerimaan retribusi daerah yang selanjutnya akan berpengaruh terhadap jumlah keseluruhan Penerimaan Asli Daerah (PAD).

Dari seluruh pasar yang terdapat di Kota Dumai, kegiatan pemungutan retribusi hanya aktif pada 2 kecamatan, yaitu di Kecamatan Dumai Timur dan Kecamatan Dumai Barat. Sedangkan di 3 kecamatan lainnya tidak dilakukan pemungutan retribusi. Sehingga potensi untuk peningkatan jumlah retribusi yang dapat dipungut masih terbuka. Dari perhitungan potensi retribusi pasar dari tiap-tiap pasar di Kota Dumai, maka diketahui pedagang yang menempati los sebanyak 490 pedagang, pedagang yang menempati kios sebanyak 399 pedagang dan pedagang yang menempati lapak sebanyak 1.413 pedagang, dengan jumlah keseluruhan adalah 
2.302 pedagang. Potensi penerimaan retribusi pasar Kota Dumai, yang secara rinci dapat dilihat pada Tabel 1.

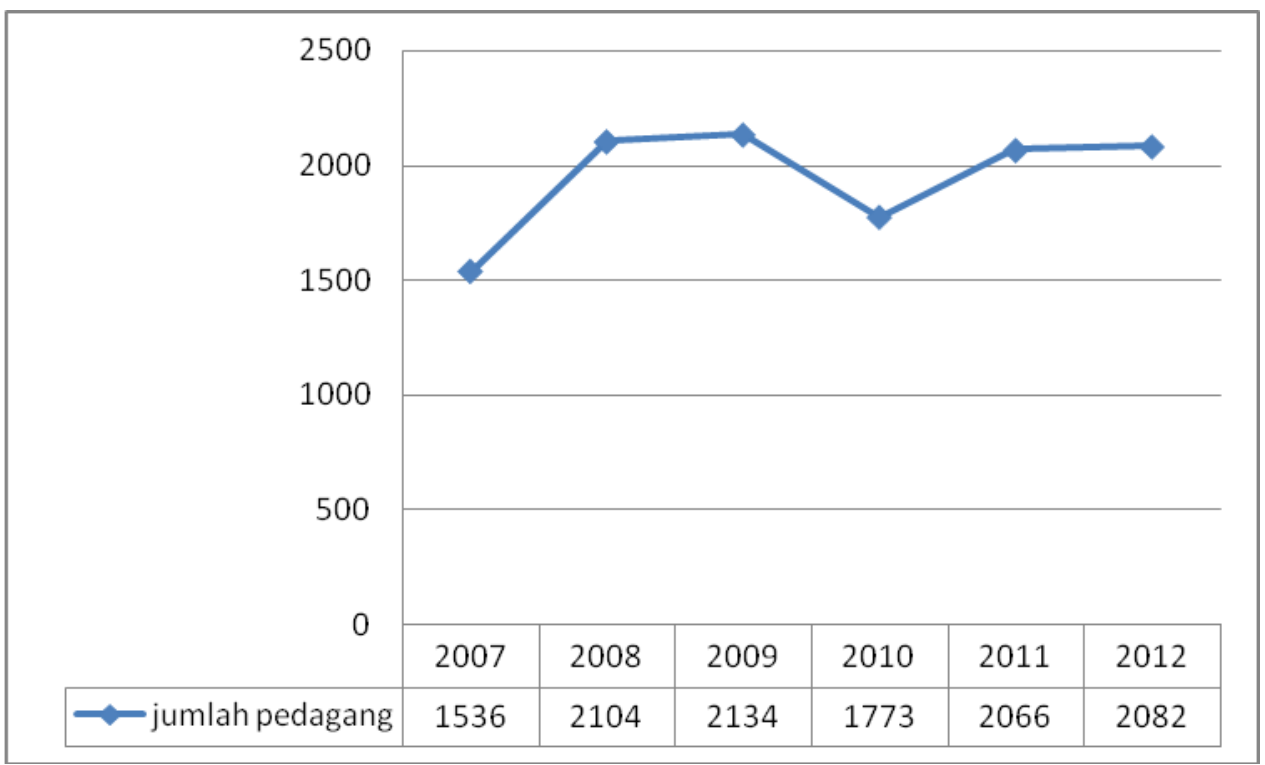

Gambar 1. Perkembangan Jumlah Pedagang di Kota Dumai Tahun 2007-2012

Tabel 1. POTENSI POTENSIAL PENERIMAAN RETRIBUSI PASAR KOTA DUMAI PER BULAN TAHUN 2011/2012 YANG DIKELOLA PEMKO DAN SWASTA

\begin{tabular}{|l|l|c|c|c|c|}
\hline No & \multicolumn{1}{|c|}{ Kecamatan } & Los & Kios & Lapak & Jumlah \\
\hline 1 & DUMAI TIMUR & 1.050 .000 & 9.270 .000 & 19.260 .000 & 29.580 .000 \\
\hline 2 & DUMAI BARAT & 50.400 .000 & 26.640 .000 & 19.125 .000 & 96.165 .000 \\
\hline 3 & BUKIT KAPUR & - & - & 15.300 .000 & 15.300 .000 \\
\hline 4 & MEDANG KAMPAI & - & - & 7.650 .000 & 7.650 .000 \\
\hline 5 & $\begin{array}{l}\text { SUNGAI } \\
\text { SEMBILAN }\end{array}$ & - & - & 2.250 .000 & 2.250 .000 \\
\hline \multicolumn{2}{|l|}{ TOTAL } & 51.450 .000 & 35.910 .000 & 63.585 .000 & 150.945 .000 \\
\hline
\end{tabular}

Sumber : Kantor Pelayanan Pasar Kota Dumai, diolah

Dari hasil perhitungan di atas terlihat bahwa potensi potensial penerimaan retribusi pasar Kota Dumai cukup besar yaitu Rp. 150.945.000 per bulan atau Rp. 1.811.340.000 per tahun. Perhitungan ini diasumsikan bahwa kegiatan pemungutan retribusi pasar di seluruh pasar di Kota Dumai baik yang dikelola oleh Pemerintah Kota Dumai dan Swasta berjalan dengan baik (aktif) dan seluruh pedagang menyetor retribusi dengan teratur. 
Target yang ditetapkan oleh Pemerintah Kota Dumai pada tahun 2012 hanya sebesar Rp. 250.000.000 per tahun. Target ini tentunya masih jauh dari potensi yang seharusnya bisa dicapai oleh pemerintah Kota Dumai, apa bila kita melihat potensi aktual yang telah dilakukan oleh Pemerintah Kota Dumai. Target yang ditetapkan oleh Pemerintah Kota Dumai hanya berkisar 13.8 persen dari potensi yang seharusnya dapat diraih. Atau apa bila kita hanya memperhitungkan pada pasar-pasar yang aktif dalam pemungutan retribusi pasar maka target yang telah ditetapkan oleh pemerintah Kota Dumai juga masih jauh dari potensinya, yaitu hanya sebesar 16.57 persen.

Demikian pula apabila kita melihat realisasi penyetoran retribusi pelayanan pasar masih jauh dari harapan. Bahkan terhadap target yang telah ditetapkan oleh pemerintah pada tahun 2012 masih jauh dari harapan. Sampai bulan April 2012, penerimaan yang diperoleh baru sebesar Rp. 49.311.000 atau baru sekitar 19.72 persen.

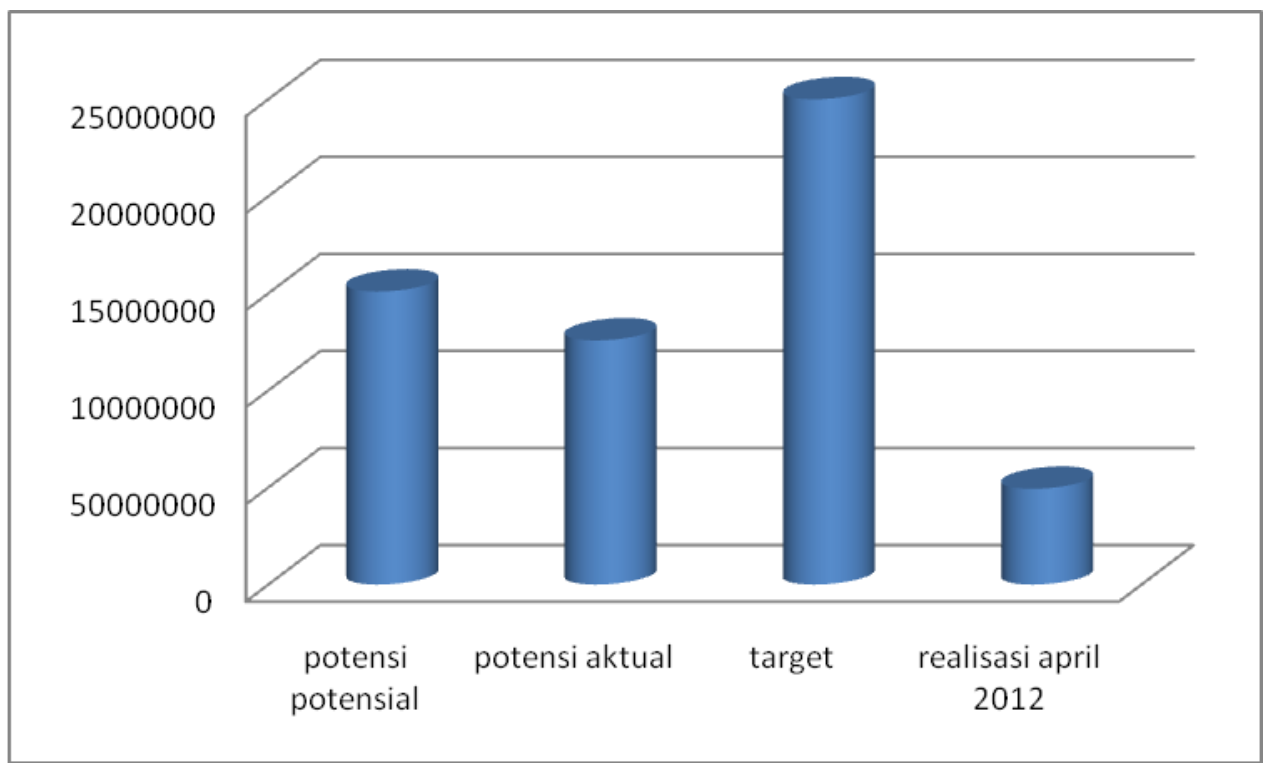

\section{Gambar 2. Komposisi Potensi Potensial, Potensi Aktual, Target dan Realisasi Penerimaan Retribusi Pelayanan Pasar di Kota Dumai}

\section{Kontribusi Retribusi Pasar Terhadap Penerimaan Asli Daerah (PAD) Kota Dumai}

Untuk itu perlu diketahui kontribusi atau sumbangan retribusi pasar terhadap PAD, yaitu dengan membandingkan realisasi antara retribusi pelayanan pasar dengan PAD. Perkembangan retribusi pasar di Kota Dumai untuk tahun anggaran 2006 sampai dengan 2010 dapat dilihat dalam Tabel 2. 
Tabel 2. KONTRIBUSI RETRIBUSI PELAYANAN PASAR TERHADAP PENERIMAAN ASLI DAERAH

KOTA DUMAI TAHUN 2006-2010 (Dalam Juta)

\begin{tabular}{|c|r|r|c|}
\hline Tahun & $\begin{array}{c}\text { Retribusi Pasar } \\
\text { (dalam Jutaan) }\end{array}$ & $\begin{array}{c}\text { PAD } \\
\text { (Dalam Jutaan) }\end{array}$ & $\begin{array}{c}\text { Kontribusi } \\
(\mathbf{\%})\end{array}$ \\
\hline 2006 & 40,05 & 16.624 & 0.24 \\
\hline 2007 & 66,34 & 19.223 & 0.34 \\
\hline 2008 & 89,05 & 40.867 & 0.22 \\
\hline 2009 & 71,77 & 41.469 & 0.17 \\
\hline 2010 & 78,12 & 41.301 & 0.19 \\
\hline Rata-rata & 69,07 & 31.897 & 0.23 \\
\hline
\end{tabular}

Sumber : Kantor Pelayanan Pasar Kota Dumai, diolah

Dari perhitungan tabel 2. di atas dapat dilihat bahwa kontribusi retribusi pelayanan pasar di Kota Dumai terhadap Pendapatan Asli Daerah (PAD) masih kecil, karena rata-rata masih dibawah 1 persen, yaitu rata-rata hanya sekitar 0.23 persen saja. Pada tahun anggaran 2006-2010 kontribusi retribusi pelayanan pasar terhadap PAD cukup berfluktuasi antara 0.17-0.34 persen.

\section{Tingkat Pertumbuhan}

Retribusi pelayanan pasar merupakan salah satu pendapatan dari pendapatan daerah yang digunakan sebagai sumber dana bagi pembiayaan pembangunan. Realisasi penerimaan retribusi pelayanan pasar di Kota Dumai pada tiap-tiap tahun anggaran bervariasi (lihat Tabel 3). Untuk itu Pemerintah Kota Dumai berusaha untuk terus menggalinya agar dapat meningkatkan penerimaan tiap tahunnya.

Tabel 3. TINGKAT PERTUMBUHAN RETRIBUSI PASAR KOTA DUMAI TAHUN 2006-2010 (Dalam Juta)

\begin{tabular}{|c|c|c|}
\hline Tahun & $\begin{array}{c}\text { Ralisasi } \\
\text { (dalam Jutaan) }\end{array}$ & $\begin{array}{c}\text { Pertumbuhan } \\
(\boldsymbol{\%})\end{array}$ \\
\hline 2006 & 40,05 & - \\
\hline 2007 & 66,34 & 65.64 \\
\hline 2008 & 89,05 & 34.23 \\
\hline 2009 & 71,77 & -19.40 \\
\hline 2010 & 78,12 & 8.85 \\
\hline
\end{tabular}

Sumber : Kantor Pelayanan Pasar Kota Dumai, diolah 
Berdasarkan Tabel 3, dapat di ketahui tingkat pertumbuhan terendah terjadi pada tahun 2009, yaitu $-19,40$ persen dari realisasi penerimaan tahun 2008. Pada tahun 2010, tingkat pertumbuhan retribusi pasar di Kota Dumai mengalami kenaikan kembali sebesar 8,85 persen. Namun demikian secara umum terjadi penurunan tingkat pertumbuhan penerimaan retribusi pelayanan pasar sejak tahun anggaran 2006.

\section{Tingkat Pencapaian Target Retribusi (TPT)}

Tingkat pencapaian target retribusi adalah hubungan antara hasil penerimaan retribusi dari retribusi terhadap potensi retribusi. Perhitungan TPT ini bertujuan untuk mengetahui apakah potensi yang ditetapkan pada awal tahun anggaran dapat dicapai pada akhir periode tahun anggaran. Untuk perhitungan TPT retribusi daerah dapat ditunjukkan dengan nilai $100 \%$ atau sama antara jumlah penerimaan dengan jumlah yang ditargetkan.

Tabel 4 TINGKAT PERTUMBUHAN RETRIBUSI PASAR KOTA DUMAI TAHUN 2003-2009

\begin{tabular}{|c|c|c|c|}
\hline Tahun & $\begin{array}{c}\text { Target } \\
\text { (dalam Jutaan) }\end{array}$ & $\begin{array}{c}\text { Ralisasi } \\
\text { (dalam Jutaan) }\end{array}$ & $\begin{array}{c}\text { TPT } \\
(\boldsymbol{\%})\end{array}$ \\
\hline 2005 & 32,20 & 32,70 & 101,55 \\
\hline 2006 & 37,03 & 40,05 & 108,15 \\
\hline 2007 & 60,00 & 66,34 & 110,57 \\
\hline 2008 & 66,52 & 89,05 & 133,87 \\
\hline 2009 & 90,00 & 71,77 & 79,74 \\
\hline 2010 & 90,00 & 78,12 & 86,80 \\
\hline 2011 & 100,00 & 122,00 & 122,00 \\
\hline
\end{tabular}

Sumber : Kantor Pelayanan Pasar Kota Dumai, diolah

Dari Tabel 4. dapat diketahui bahwa TPT retribusi pelayanan pasar Kota Dumai selama tujuh tahun dari tahun anggaran 2005 sampai dengan tahun anggaran 2011 bisa dikatakan tercapai. Meskipun secara nyata TPT penerimaan retribusi daerah ada yang mempunyai nilai kurang dari 100 persen yaitu pada tahun anggaran 2009 dan 2010 akan tetapi keadaan ini menunjukkan bahwa penerimaan dari retribusi pelayanan pasar Kota Dumai relatif masih cukup baik. Hal ini dikarenakan dalam perhitungan yang dilakukan dalam tujuh tahun anggaran lebih banyak yang mencapai nilai TPT diatas 100 persen atau selalu melampui target retribusinya dengan rata-rata sebesar 103.45 persen. 


\section{Elastisitas}

Perhitungan elastisitas ini bertujuan untuk mengetahui kepekaan perubahan retribusi yang menyebabkan perubahan PAD. Adapun hasil perhitungan dari elastisitasnya terdapat dalam Tabel 5 sebagai berikut :

Tabel 5 ELASTISITAS RETRIBUSI PELAYANAN PASAR KOTA DUMAI TAHUN 2006-2010

\begin{tabular}{|c|c|c|c|c|c|}
\hline Tahun & $\begin{array}{c}\text { Ralisasi } \\
\text { (dalam } \\
\text { Jutaan) }\end{array}$ & $\begin{array}{c}\text { Perubahan } \\
\text { Penerimaan } \\
\text { Retribusi }\end{array}$ & $\begin{array}{c}\text { PAD } \\
\text { (dalam } \\
\text { jutaan) }\end{array}$ & $\begin{array}{c}\text { Perubahan } \\
\text { Penerimaan } \\
\text { PAD }\end{array}$ & $\begin{array}{c}\text { Elastisitas } \\
(\%)\end{array}$ \\
\hline 2006 & 40,05 & - & 16.624 & - & - \\
\hline 2007 & 66,34 & 26,29 & 19.223 & 2.599 & 0,34 \\
\hline 2008 & 89,05 & 22,71 & 40.867 & 21.644 & 2,08 \\
\hline 2009 & 71,77 & $-17,28$ & 41.469 & 602 & 0,06 \\
\hline 2010 & 78,12 & 6,35 & 41.301 & -168 & 0,05 \\
\hline
\end{tabular}

Sumber : Pemerintah Kota Dumai, diolah

Dilihat dari Tabel 5 diatas dapat diketahui bahwa elastisitas retribusi pelayanan pasar terhadap PAD di Kota Dumai tahun anggaran 2006 - 2010 berbeda beda. Tahun anggaran 2007 besarnya elastisitas 0,34 berarti setiap kenaikan retribusi sebesar 1 persen menyebabkan kenaikan PAD sebesar 0,34 persen atau tidak banyak terjadi perubahan pada PAD atau retribusinya relatif tidak peka terhadap PAD (inelastis). Tahun anggaran 2008 besarnya elastisitas 2,08 berarti setiap kenaikan retribusi sebesar 1 persen menyebabkan kenaikan PAD sebesar 2,08 persen atau terjadi perubahan yang cukup besar pada PAD atau retribusinya relatif peka terhadap PAD (elastis). Selanjutnya tahun anggaran 2009 dan 2010 elastisitasnya masingmasing sebesar elastisitasnya sebesar 0,06 dan 0,05 persen, yang berarti setiap kenaikan retribusi sebesar 1 persen menyebabkan kenaikan PAD sebesar 0,06 persen dan 0,05 persen atau tidak banyak terjadi perubahan pada PAD atau retribusi pelayanan pasar relatif tidak peka terhadap PAD (inelastis).

\section{Analisis Trend.}

Trend adalah rata-rata perubahan (biasanya setiap tahun) dalam jangka panjang. Analisis ini bertujuan untuk mengetahui prospek penerimaan retribusi sebagai salah satu sumber pengeluaran rutin dimana retribusi merupakan salah satu 
sumber penerimaan dalam PAD. Dalam analisis ini akan dicoba untuk menganalis trend terhadap retribusi pelayanan pasar dan PAD.

\section{Analisis Trend Retribusi Pasar}

Hasil perhitungan trend pada retribusi pelayanan pasar diperoleh persamaan trendnya yaitu $\mathrm{Y}^{\prime}=66.1+9.92 \mathrm{X}$. Dari perhitungan analisis trend retribusi yang dilakukan dapat digunakan untuk memproyeksikan penerimaan retribusi daerah pada tahun yang akan datang. Dari persamaan trend tersebut menunjukkan bahwa cenderung terjadi peningkatan disetiap tahunnya dan ini berarti trendnya positif.

Untuk melihat perkembangan trend retribusi pelayanan pasar yang terjadi dapat pula dilihat dalam bentuk grafiknya sebagai berikut :

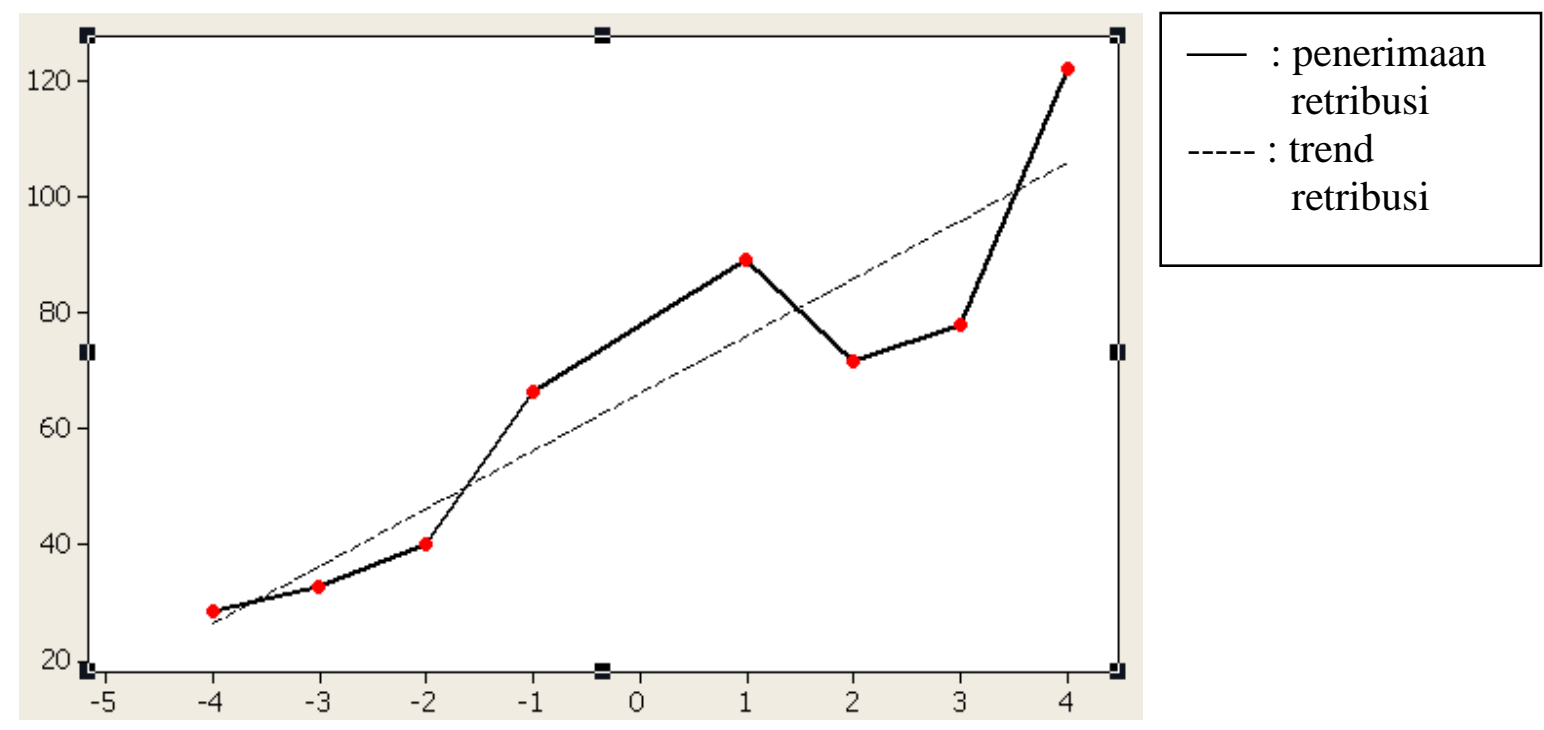

\section{Gambar 3. Trend Retribusi Pasar Kota Dumai Tahun 2004 - 2011}

\section{Analisis Trend PAD}

Analisis berikut ini mencoba untuk melihat trend yang terjadi pada realisasi PAD Kota Dumai. Dari perhitungan yang dilakukan diperoleh rumus persamaan trendnya. Adapun dari hasil perhitungan trend pada PAD kota Dumai diperoleh persamaan trendnya yaitu :

$$
\mathrm{Y}^{\prime}=31897+7160 \mathrm{X}
$$

Dari perhitungan analisis trend PAD Kota Dumai yang dilakukan dapat digunakan untuk memproyeksikan penerimaan PAD pada tahun yang akan datang. 
Dari persamaan trend tersebut menunjukkan bahwa cenderung terjadi peningkatan disetiap tahunnya dan ini berarti trendnya positif. Untuk melihat perkembangan trend PAD yang terjadi dapat dilihat dalam grafik sebagai berikut :

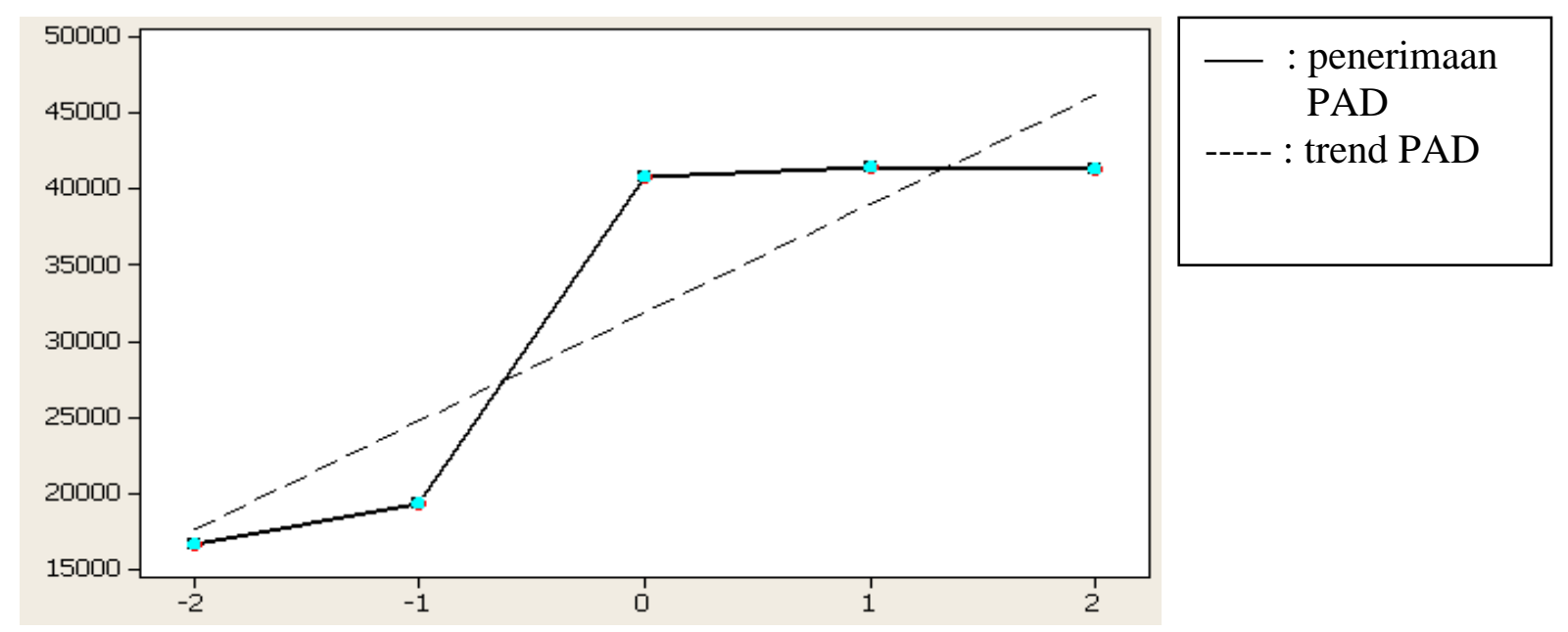

\section{Gambar V-5. Trend Retribusi Pasar Kota Dumai \\ Tahun 2006 - 2010}

\section{SIMPULAN}

Berdasarkan hasil dari analisis dan uraian pada bab-bab sebelumnya, maka dapat diambil simpulan sebagai berikut :

1. Dari hasil analisis kontribusi penerimaan Retribusi Pelayanan Pasar Kota Dumai terhadap Pendapatan Asli Daerah (PAD) Kota Dumai tahun anggaran 2006 2010 masih kecil, . karena rata-rata masih dibawah 1 persen, yaitu rata-rata hanya sekitar 0.23 persen saja. Pada tahun anggaran 2006-2010 kontribusi retribusi pelayanan pasar terhadap PAD cukup berfluktuasi antara 0.17-0.34 persen.

2. Hasil analisis menunjukkan bahwa tingkat pertumbuhan Retribusi Pelayanan Pasar Kota Dumai secara umum terjadi penurunan tingkat pertumbuhan penerimaan retribusi pelayanan pasar sejak tahun anggaran 2006 hingga 2010.

3. Tingkat efektifitas Retribusi Pelayanan Pasar Kota Dumai ditunjukkan oleh Tingkat Pencapaian Target (TPT) retribusi pelayanan pasar Kota Dumai selama tujuh tahun dari tahun anggaran 2005 sampai dengan tahun anggaran 2011 bisa dikatakan tercapai. Hal ini dikarenakan dalam perhitungan yang dilakukan dalam tujuh tahun anggaran lebih banyak yang mencapai nilai TPT diatas 100 persen atau selalu melampui target retribusinya. Dengan rata-rata sebesar 103.45 
persen setiap tahunnya, hal ini menunjukkan bahwa kinerja dalam pemungutan Retribusi Pelayanan Pasar Kota Dumai cukup baik.

\section{DAFTAR PUSTAKA}

Kaho, Josef Riwu (1997), Prospek Otonomi Daerah di Negara Republik Indonesia, PT.Grafindo Persada, Jakarta.

Prakoso, Kesit Bambang (2003), Pajak dan Retribusi Daerah, UII Press, Yogyakarta.

Anonymous. 2010. Kota Dumai Dalam Angka 2010. Dumai : BPS.

Saragih, Juli Panglima (2003), Desentralisasi Fiskal dan Keuangan Daerah dalam Otonomi, Ghalia Indonesia, Jakarta.

Yani, Ahmad (2002), Hubungan Keuangan Antara Pemerintah Pusat dan Daerah di Indonesia, PT.Raja Grafindo, Jakarta.

Undang-Undang Nomor 32 tahun 2004 tentang Pemerintah Daerah dan UndangUndang Nomor 28 tahun 2009 tentang Pajak Daerah dan Retribusi Daerah.

Peraturan Pemerintah Nomor 66 tahun 2001 tentang Retribusi Daerah.

Undang-Undang Nomor 32 Tahun 2004 tentang Pemerintahan Daerah sebagaimana telah dirubah beberapa kali terakhir dengan undang-undang nomor 12 tahun 2008 .

Undang-Undang Nomor 33 Tahun 2004 tentang Perimbangan Keuangan antara Pemerintahan Pusat dan Pemerintahan Daerah.

Undang-undang Nomor 28 Tahun 2009 tentang Pajak Daerah dan Retribusi Daerah. Peraturan Pemerintah Nomor 25 tahun 2000 tentang Kewenangan Pemerintah dan Kewenangan Provinsi sebagai Daerah Otonom.

Peraturan Pemerintah Nomor 66 Tahun 2001 tentang Retribusi Daerah.

Peraturan Pemerintah Nomor 6 Tahun 2006 tentang Pengelolaan Barang Milik Negara/ Daerah

Peraturan Pemerintah Nomor 38 Tahun 2007 tentang Pembagian Urusan Pemerintahan antara Pemerintah, Pemerintah Daerah Provinsi, dan Pemerintah Daerah Kabupaten/Kota

Keputusan Menteri Dalam Negeri Nomor 174 tahun 1997 tentang Pedoman Tata Cara Pemungutan Retribusi Daerah.

Keputusan Menteri Dalam Negeri Nomor 175 tahun 1997 tentang Tata Cara Pemeriksaan di Bidang Retribusi Daerah. 
Keputusan Menteri Dalam Negeri Nomor 119 tahun 1998 tentang Ruang Lingkup dan jenis-jenis Retribusi Daerah Tingkat I dan Daerah Tingkat II.

Keputusan Menteri Dalam Negeri Nomor 245 tahun 2004 tentang Pedoman Penetapan Tarif Retribusi Jasa Umum.

Peraturan Menteri Perdagangan Nomor : 53/M-DAG/PER/12/2008 tentang Pedoman Penataan dan Pembinaan Pasar Tradisonal, Pusat Perbelanjaan dan Toko Modern.

Peraturan Daerah Kota Dumai Nomor 6 Tahun 2001 tentang Organisasi dan Tata Kerja Lembaga Teknis Daerah sebagaimana dirubah dengan Peraturan Daerah Kota Dumai Nomor 5 Tahun 2002 tentang Perubahan Peraturan Kota Dumai Nomor 6 Tahun 2001.

Peraturan Daerah Kota Dumai No. 8 tahun 2002 tentang Retribusi Pelayanan Pasar dirubah dengan Peraturan Daerah Kota Dumai No. 21 tahun 2011 tentang Retribusi Pelayanan Pasar.

Perubahan Keputusan Walikota Dumai Nomor: 170/KPP/2009 tentang Biaya Tambahan Bagi Pedagang yang Menempati Kios, Los dan Lapak di Luar Retribusi pada Pasar Milik Pemerintah Kota Dumai.

Peraturan Daerah Kota Dumai Nomor 15 Tahun 2008 tentang Organisasi dan Tata Kerja Lembaga Teknis Daerah 